National Water Quality Program

\title{
Point-Source Nutrient Loads to Streams of the Conterminous United States, 2012
}

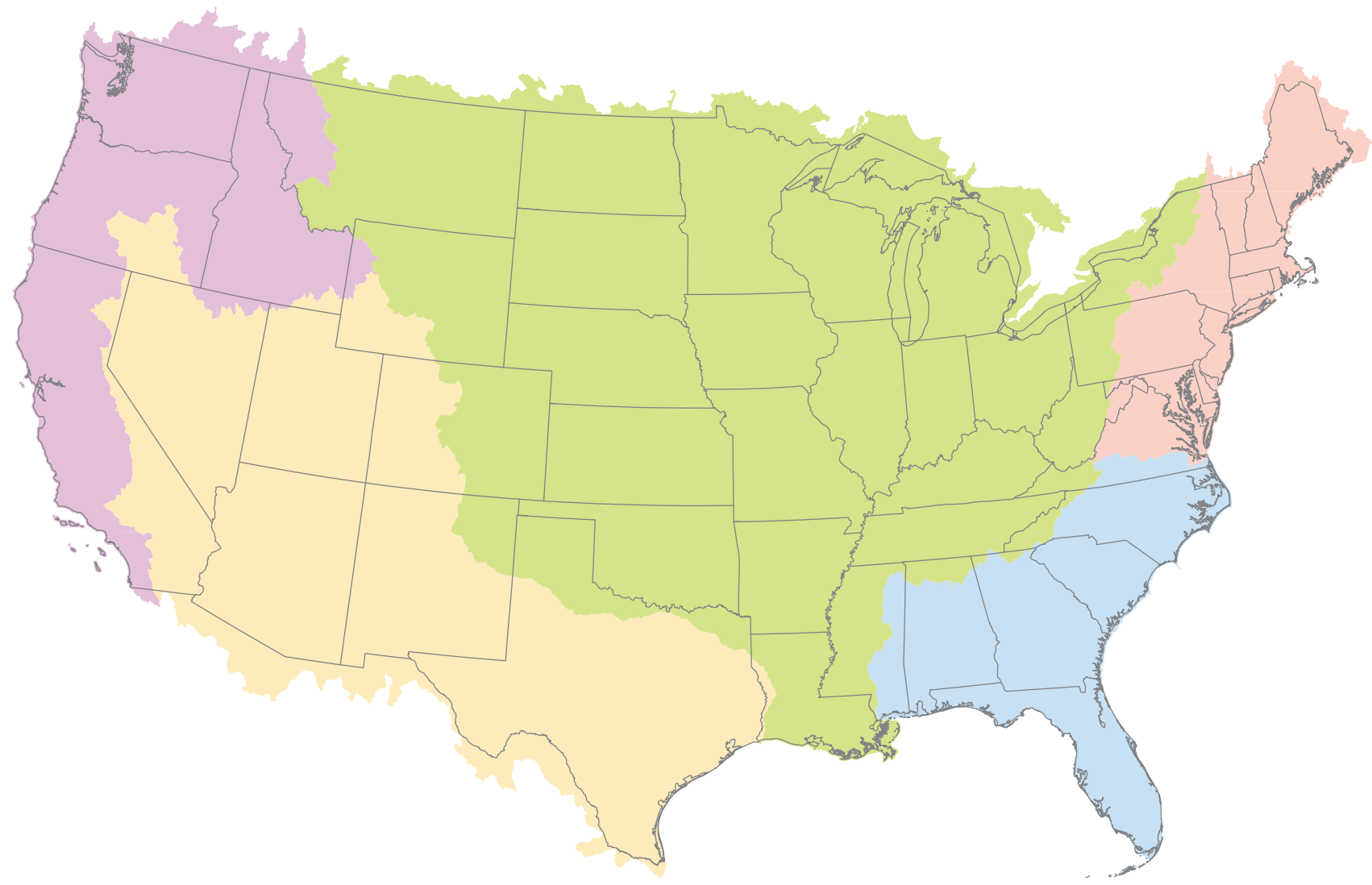

Data Series 1101

U.S. Department of the Interior

U.S. Geological Survey 
Cover: Map showing SPARROW regions in the conterminous United States during 2012. 


\section{Point-Source Nutrient Loads to Streams of the Conterminous United States, 2012}

By Kenneth D. Skinner and Molly A. Maupin

National Water Quality Program

Data Series 1101

U.S. Department of the Interior

U.S. Geological Survey 


\title{
U.S. Department of the Interior David Bernhardt, Acting Secretary
}

\author{
U.S. Geological Survey \\ James F. Reilly II, Director
}

U.S. Geological Survey, Reston, Virginia: 2019

For more information on the USGS - the Federal source for science about the Earth, its natural and living resources, natural hazards, and the environment-visit https://www.usgs.gov or call 1-888-ASK-USGS.

For an overview of USGS information products, including maps, imagery, and publications,

visit https://store.usgs.gov.

Any use of trade, firm, or product names is for descriptive purposes only and does not imply endorsement by the U.S. Government.

Although this information product, for the most part, is in the public domain, it also may contain copyrighted materials as noted in the text. Permission to reproduce copyrighted items must be secured from the copyright owner.

Suggested citation:

Skinner, K.D., and Maupin, M.A., 2019, Point-source nutrient loads to streams of the conterminous United States, 2012: U.S. Geological Survey Data Series 1101, 13 p., https://doi.org/10.3133/ds1101.

ISSN 2327-638X (online) 


\title{
Foreword
}

Sustaining the quality of the Nation's water resources and the health of our diverse ecosystems depends on the availability of sound water-resources data and information to develop effective, science-based policies. Effective management of water resources also brings more certainty and efficiency to important economic sectors. Taken together, these actions lead to immediate and long-term economic, social, and environmental benefits that make a difference to the lives of the almost 400 million people projected to live in the United States by 2050.

In 1991, Congress established the National Water-Quality Assessment (NAWQA) to address where, when, why, and how the Nation's water quality has changed, or is likely to change in the future, in response to human activities and natural factors. Since then, NAWQA has been a leading source of scientific data and knowledge used by national, regional, state, and local agencies to develop science-based policies and management strategies to improve and protect water resources used for drinking water, recreation, irrigation, energy development, and ecosystem needs (https://water.usgs.gov/nawqa/applications/). Plans for the third decade of NAWQA (2013-23) address priority water-quality issues and science needs identified by NAWQA stakeholders, such as the Advisory Committee on Water Information and the National Research Council, and are designed to meet increasing challenges related to population growth, increasing needs for clean water, and changing land-use and weather patterns.

Federal, state, and local agencies have invested billions of dollars to reduce the amount of pollution entering rivers and streams that millions of Americans rely on for a variety of water needs and biota rely on for habitat. Understanding the sources and transport of pollution is crucial for designing strategies to improve water quality. The U.S. Geological Survey's SPAtially Referenced Regressions On Watershed attributes (SPARROW) model was developed to aid in the understanding of sources and transport of pollution across large spatial scales. The SPARROW model is calibrated by statistically relating watershed sources and transport-related properties to monitoring-based water-quality load estimates. This report describes how total nitrogen and phosphorous loads were estimated for 5,430 major point-source facilities and 11,537 minor wastewater treatment facilities discharging to streams in the conterminous United States during 2012. Point-source data were compiled from the U.S. Environmental Protection Agency's (EPA) Permit Compliance System (PCS) and Integrated Compliance Information System (ICIS) databases. The report also describes a new method to calculate typical pollutant concentrations for use in the absence of point-source nutrient concentrations.

We hope this publication will provide insights and information to meet water-resource needs and will foster increased citizen awareness and involvement in the protection and restoration of our Nation's waters. The information in this report is intended primarily for those interested in or involved in resource management and protection, conservation, regulation, and policymaking at the regional and National levels.

\author{
Dr. Donald W. Cline \\ Associate Director for Water \\ U.S. Geological Survey
}




\section{Contents}

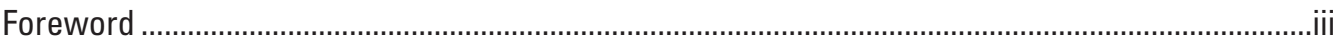

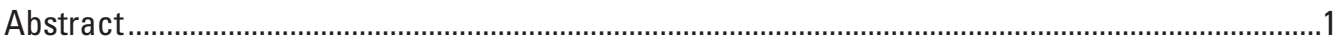

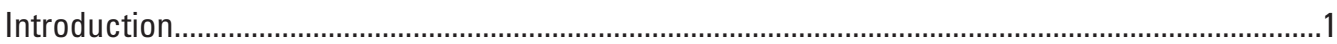

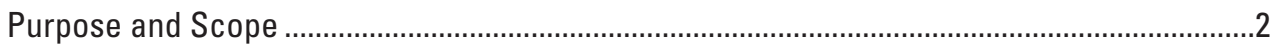

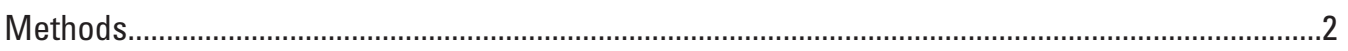

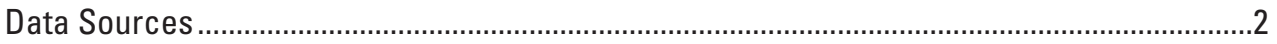

Permit Compliance System and Integrated Compliance Information System .................2

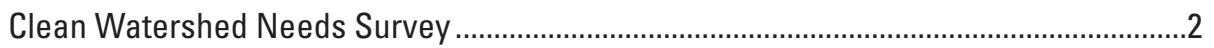

Point-Source Data Quality Assurance and Quality Control ...........................................................

Updated Methods from Previous Studies................................................................................

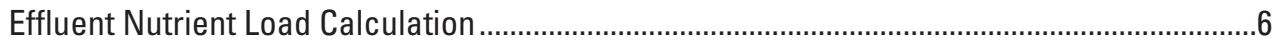

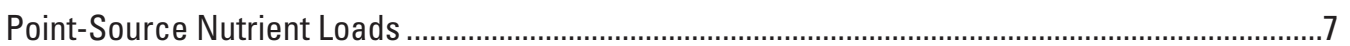

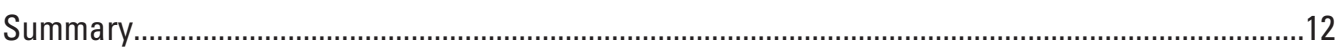

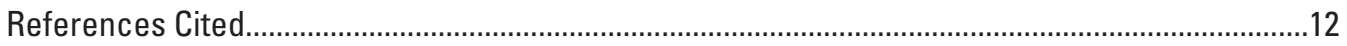

\section{Figures}

1. Map showing major point-source facilities and minor wastewater treatment facilities in the conterminous United States, 2012

2. Map showing example of state expansion levels for determining typical pollutant concentration values

3. Graphs showing comparison of nutrient loads from 2012 data derived from the Maupin and Ivahnenko (2011) method and the varying concentration and facility typical pollutant concentration method.

4. Graphs showing percentage of measured and typical pollutant concentration values used to determine nutrient loads to streams by state, 2012 .

5. Graphs showing total nitrogen $(A)$ and phosphorous $(B)$ loads in streams by state, 2012

6. Pie graphs showing total nitrogen $(A)$ and total phosphorous $(B)$ loads by standard industry classification code (SIC) and treatment level for 2012

7. Graphs showing total nitrogen $(A)$ and total phosphorous $(B)$ loads by major and minor wastewater treatment facilities in states for 2012. 


\section{Conversion Factors}

Inch/Pound to International System of Units

\begin{tabular}{lll}
\hline & Bultiply & To obtain \\
\hline mile $(\mathrm{mi})$ & Length & \\
\hline & 1.609 & kilometer $(\mathrm{km})$ \\
\hline million gallons per day $(\mathrm{Mgal} / \mathrm{d})$ & Flow rate & \\
\hline
\end{tabular}

International System of Units to U.S. customary units

\begin{tabular}{lll}
\hline \multicolumn{1}{c}{ Multiply } & By & \multicolumn{1}{c}{ To obtain } \\
\hline kilogram $(\mathrm{kg})$ & Mass & \\
kilogram per year $(\mathrm{kg} / \mathrm{yr})$ & 2.205 & pound avoirdupois $(\mathrm{lb})$ \\
\hline
\end{tabular}

\section{Datum}

Horizontal coordinate information is referenced to the North American Datum of 1983 (NAD 83).

Altitude, as used in this report, refers to distance above the vertical datum.

\section{Supplemental Information}

Concentrations of chemical constituents in water are given in milligrams per liter (mg/L). 


\section{Abbreviations}

$\begin{array}{ll}\text { CWNS } & \text { Clean Watershed Needs Survey } \\ \text { DMR } & \text { discharge monitoring report } \\ \text { EPA } & \text { U.S. Environmental Protection Agency } \\ \text { ICIS } & \text { Integrated Compliance Information System } \\ \text { MRB } & \text { major river basin } \\ \text { NHDPlus } & \text { National Hydrography Dataset version 2 } \\ \text { NPDES } & \text { National Pollutant Discharge Elimination System } \\ \text { PCS } & \text { Permit Compliance System } \\ \text { PSLoadEsT } & \text { Point Source Load Estimation Tool } \\ \text { SIC } & \text { standard industry classification code } \\ \text { SPARROW } & \text { SPAtially Referenced Regressions On Watershed attributes } \\ \text { TN } & \text { total nitrogen } \\ \text { TP } & \text { total phosphorous } \\ \text { TPC } & \text { typical pollutant concentration } \\ \text { USGS } & \text { U.S. Geological Survey } \\ \text { WWTF } & \text { wastewater treatment facility }\end{array}$




\title{
Point-Source Nutrient Loads to Streams of the Conterminous United States, 2012
}

\author{
By Kenneth D. Skinner and Molly A. Maupin
}

\section{Abstract}

Total nitrogen and phosphorous loads were estimated for 5,430 major point-source facilities (all types) and 11,537 minor wastewater treatment facilities discharging to streams in the conterminous United States during 2012. Facilities classified as a major discharger are typically a facility that discharges greater than one million gallons of water per day however some industrial facilities are classified as a major based on specific criteria developed by the U.S. Environmental Protection Agency (EPA) and the National Pollutant Discharge Elimination System state program. Data documenting discharge information from point sources were obtained from the EPA's Integrated Compliance Information System (ICIS) and Permit Compliance System (PCS). When available, actual nutrient concentration measurements were used to calculate point-source loads. In the many cases in which concentration data were not available in either the ICIS or PCS databases, typical pollutant concentrations (TPCs) were developed using data from similar facilities. A new method for calculating TPCs was implemented that allows varying amounts of nutrient concentration data and (or) varying numbers of facilities to determine TPCs. This new method minimized the effect that any single facility discharging extremely large nutrient concentrations had on resultant TPC values. Because of the smaller TPC values from this new TPC method, the total nutrient load for many states was reduced compared to previous TPC methods.

Major wastewater treatment facilities are the largest contributor of nutrient loads to streams even though there are almost three times as many minor wastewater treatment facilities. Specifically, 4,218 major wastewater treatment facilities account for 94 percent of the total nitrogen load for the conterminous United States, whereas 11,397 minor wastewater treatment facilities contribute 6 percent of the total nitrogen load. Total phosphorous loads are similarly divided among major (93 percent) and minor ( 7 percent) wastewater treatment facilities. Total nitrogen loads, including all facility types, primarily are from wastewater treatment facilities and some petroleum refining facilities. Total phosphorous loads also are primarily from wastewater treatment facilities, but several manufacturing facilities such as corn milling, pulp and paper mills, and industrial chemical facilities also contribute to total phosphorous loads.

\section{Introduction}

The U.S. Geological Survey (USGS) developed a spatial water-quality model called SPAtially Referenced Regressions On Watershed attributes (SPARROW) to estimate the major sources and environmental factors that affect the long-term supply, transport, and fate of contaminants in the Nation's streams (Smith and others, 1997; Schwarz and others, 2006; Preston and others, 2011). The SPARROW model relates in-stream water-quality data to spatially referenced characteristics of watersheds, including contaminant sources and factors influencing terrestrial and aquatic transport. Based on SPARROW modeling, one of the main nutrient sources to streams is point-source facilities such as municipal wastewater treatment facilities (WWTFs) that discharge directly to streams (Alexander and others, 2008, Preston and others, 2011, Robertson and Saad, 2011).

Consistent and reliable data about point-source dischargers are difficult to acquire, especially at the national scale (Maupin and Ivahnenko, 2011). Point-source flow and effluent concentrations are available from the U.S. Environmental Protection Agency's (EPA) Permit Compliance System (PCS) and Integrated Compliance Information System (ICIS) databases as required by the Clean Water Act of 1972 to monitor facility compliance. However, individual states provide the data stored in the EPA databases and participation in submitting data and the quality of the submitted data is often highly variable. Maupin and Ivahnenko (2011) documented methods derived from the U.S. Environmental Protection Agency (2006a, 2006b) and McMahon and others (2007) to address data gaps and to develop a consistent dataset with established quality-control and quality assurance procedures. 


\section{Purpose and Scope}

This report provides estimates of annual total nitrogen (TN) and total phosphorous (TP) loads for all major pointsource facilities and minor wastewater treatment facilities discharging to streams in the conterminous United States during 2012. It also describes an updated method of determining typical pollutant concentrations (TPC) used in the absence of measured TN or TP concentration data.

\section{Methods}

The methods used to compile, check, and calculate pointsource nutrient loads closely followed those of McMahon and others (2007) and Maupin and Ivahnenko (2011). Point-source loads were estimated for all major point-source facilities as in the previous work. However, instead of including all minor facilities of any type as did Maupin and Ivahnenko (2011), only minor municipal WWTFs were considered because only minor WWTFs were thought to be the largest contributor of the nutrient load. A point-source facility is classified as a major discharger by an EPA regional administrator or in conjunction with a state director if the facility is in a state with an approved National Pollutant Discharge Elimination System (NPDES) program. Major municipal dischargers include all facilities (WWTF or other) with designed flows of greater than one million gallons per day (Mgal/d) and facilities with EPA/state-approved industrial pretreatment programs. Major industrial facilities are determined based on specific ratings criteria developed by EPA and the state if an approved NPDES state program exists. Locations and estimates of annual total nitrogen (TN) and total phosphorous (TP) loads for all major point-source facilities and minor wastewater treatment facilities discharging to streams in the conterminous United States during 2012 are shown in figure 1.

Point-source facility, flow, and concentration data were compiled from several sources. Flow and concentration data for facilities were limited to the discharge point from the facility to a stream. Other measurement locations such as the input to a facility were not used. The concentration data used to calculate loads were $\mathrm{TN}$ as nitrogen and TP as phosphorous. The calculated load measured in weight per time (kilograms per year) represents the entire amount of total nitrogen and total phosphorous being contributed to a stream.

\section{Data Sources}

\section{Permit Compliance System and Integrated Compliance Information System}

Point-source discharge facility data including facility descriptions, monthly effluent flow, and monthly nutrient concentration data were compiled from several sources. A copy of EPA's PCS and ICIS databases was received directly from EPA in autumn 2013. The EPA PCS database provides information such as compliance and enforcement status on facilities that have been issued permits to discharge wastewater into streams (U.S. Environmental Protection Agency, 1990). The EPA ICIS database was implemented as a modernization of the PCS database and provides information for the NPDES program, including permit information and discharge monitoring data. The ICIS database differs from the PCS database because it also includes compliance information for air quality and hazardous waste facilities.

A review of the 2012 PCS/ICIS database revealed that a large amount of data were either questionable or missing. Routine downloads from the EPA Discharge Monitoring Report (DMR) Loading Tool (https://echo.epa.gov/trends/loadingtool) that allows searches for point-source discharge facility data, indicated that states continued to submit additional 2012 NPDES DMR data to the PCS/ICIS database, (U.S. Environmental Protection Agency, 2018a, 2018b, 2018c) for some time after 2012. In areas where NPDES facilities were known to exist but data were missing from the initial PCS/ICIS download or subsequent website downloads, individual states were contacted to access the NPDES DMR data.

\section{Clean Watershed Needs Survey}

The EPA Clean Watershed Needs Survey (CWNS) was another source of point-source discharge facility information, including facilities not identified in the EPA PCS/ICIS database downloads and state-provided information. The CWNS also provided treatment level information for WWTFs. The CWNS is a survey done every 4 years to assess the financial requirements needed to meet the water-quality goals of the Clean Water Act (U.S. Environmental Protection Agency, 2018a). The CWNS collects information on publicly owned wastewater collection and treatment facilities, stormwater and combined sewer overflow control facilities, nonpoint source pollution control projects, and decentralized wastewater management. Only CWNS facilities discharging effluent to streams were used in this data compilation. 


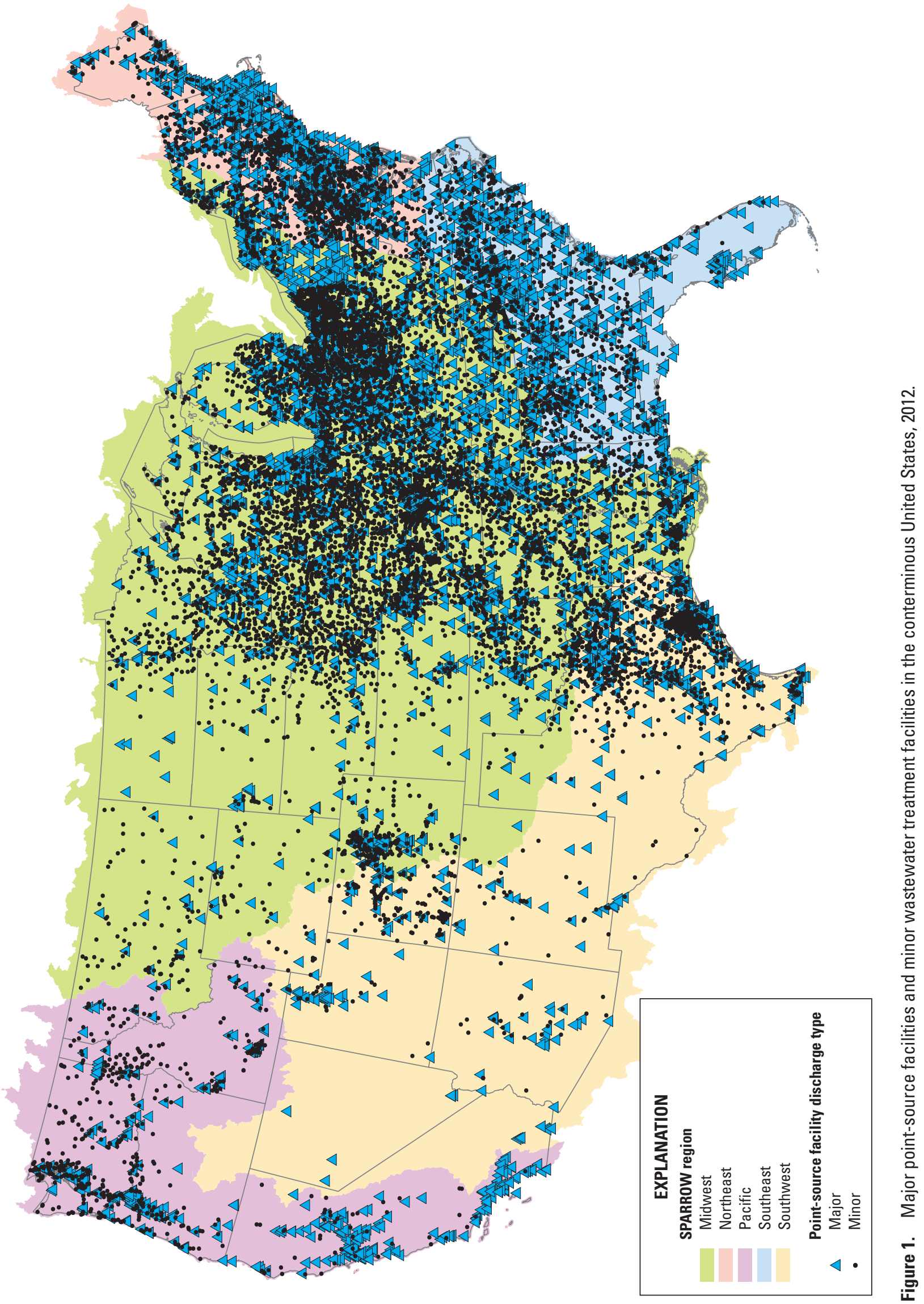


The CWNS provides treatment level information for WWTFs ranging from raw discharge to advanced treatment for nitrogen or phosphorous removal. Treatment levels were recoded for use in the SPARROW point-source load compilation according to CWNS treatment levels:

- Raw sewage discharge, coded as "0".

- Primary treatment, coded as "1" - effluent treatment by screening and sedimentation. The WWTP also has a 5-day biochemical oxygen demand (BOD5) concentration greater than 45 milligrams per liter $(\mathrm{mg} / \mathrm{L})$.

- Advanced primary treatment, coded as " $1 \mathrm{~A}$ "- effluent treatment whereby chemicals are used to further treat primary effluent and increase the amount of solid matter removed. The BOD5 concentration is greater than 30 but less than $45 \mathrm{mg} / \mathrm{L}$.

- Secondary treatment, coded as " 2 "- - effluent treatment including aeration and activated sludge. This is the minimum level of treatment required for publicly owned wastewater treatment facilities and requires minimum removal standards for BOD (less than or equal to $30 \mathrm{mg} / \mathrm{L}$ ), total suspended solids, and $\mathrm{pH}$.

- Advanced treatment, coded as " $2 \mathrm{~A}$ "- effluent treatment producing a significant reduction in nonconventional or toxic contaminants and has a BOD less than or equal to $20 \mathrm{mg} / \mathrm{L}$.

- Advanced treatment for phosphorous, coded as "3P"- a WWTF with advanced treatment emphasizing phosphorous removal.

- Advanced treatment for nitrogen, coded as " $3 \mathrm{~N}$ "WWTF with advanced treatment emphasizing the removal of nitrogen.

- Advanced treatment for nitrogen and phosphorous, coded as "3NP" - a WWTF with advanced treatment emphasizing the removal of nitrogen and phosphorous.

The 2012 CWNS was the primary source of facility treatment level information. Because the CWNS is a voluntary survey, not all WWTFs chose to participate. For example, no facilities in South Carolina participated in the 2012 CWNS. In this instance and when WWTFs from other states did not participate in the CWNS, the 2008 CWNS was used to fill in any data gaps from the 2012 CWNS.

\section{Point-Source Data Quality Assurance and Quality Control}

The point-source facility data were in various levels of quality and completeness and often contained incorrect data. Facility location information or georeferenced data were evaluated and corrected where needed. Facility location data often referred to a facility's main office address; because this study focused on point-source inputs to streams, each facility location coordinates were changed to the outfall from the facility that contributes to a stream. After an outfall location to a stream was verified, the corresponding National Hydrography Dataset (NHDPlus) unique stream identifier (ComID) (McKay and others, 2012) of the stream was assigned to the facility.

Additionally, facilities records often were either missing or had an incorrect Standard Industry Classification code, SIC code (U.S. Department of Labor, 2018), which is a four-digit numerical code used for classifying industries. The SIC codes were used in this study to group point-source facilities by similar levels of nutrient discharge. If a facility was missing a SIC code, one was assigned based on the name and regulated discharge constituents of the facility. Municipal WWTFs are some of the largest nutrient dischargers (Alexander and others, 2008, Preston and others, 2011, Robertson and Saad, 2011), so facilities were checked for incorrectly assigned SIC codes related to WWTF. Often the facility name would include "WWTP" but be assigned a SIC code related to a different industry. These codes were then changed to the SIC code related to sewerage systems (SIC 4952). For example, many point-source facilities had a SIC code for a school or correctional facility when the discharge was for a WWTF at the school or correctional facility. Updating the SIC code according to type of discharge from a facility allows for the proper assignment of TPC values if necessary and the proper grouping when summarizing nutrient loads by SIC.

\section{Updated Methods from Previous Studies}

The methods used in this study to compile, check, and calculate point-source nutrient loads followed the methods of McMahon and others (2007) and Maupin and Ivahnenko (2011) with some differences. One difference was the use of the treatment level used at a WWTF. Increased treatment levels at a WWTF can result in decreased discharged nutrient concentrations (Ivahnenko, 2017). The SIC codes for each WWTF were amended with the treatment levels described in section, "Clean Watershed Needs Survey" to create a new code for use in load calculation (for example, 4952_1A, 4952_2, 
4952 3NP). Each updated SIC code was treated as a separate unique SIC code during load calculations and, where needed, was used to create a TPC value appropriate for a WWTF with a given level of treatment.

In the two previous studies (McMahon and others, 2007; Maupin and Ivahnenko, 2011), a median seasonal flow and nutrient concentration was calculated from 3 years of data (1992, 1997, and 2002) when a facility met the condition of flow data for less than 12 months of the year and at least for three or four seasons of the year, a stipulation for using a TPC value. This report uses data from 2012 only, so seasonal medians were derived from the months of the season for 2012 . Seasons were defined as summer (June-August), autumn (September-November), winter (December-February), and spring (March-May).

The other difference occurred when a TPC value was derived from facilities in a specific geographical area. In the studies by McMahon and others (2007) and Maupin and Ivahnenko (2011), if a median seasonal concentration could not be derived, TPC values were calculated using nutrient concentration data from other facilities of the same size (based on flow) and type (SIC code) from within the same major river basin (MRB). If that still did not provide enough nutrient concentration data, then the median calculation was expanded to include all facilities of the same size and type in all MRBs. For this report, a MRB was not used as a geographical unit, but instead all geographic aggregation was based on states. Specifically, TPC values were calculated from facilities of the same size and type in the state in which the facility resides. If this did not result in enough concentration data to calculate a TPC, then the geographical area was expanded to include all surrounding states. A second expansion to the second layer of bordering states occurred if still more concentration data were required to calculate a TPC; if that was still not enough data, then the geographical area was expanded to the conterminous United States (fig. 2).

The last difference was the number of sources of effluent nutrient concentration data required to calculate a TPC value. In the previous studies, a minimum of five effluent nutrient concentration values from at least one facility were required to determine a TPC value. However, for this study the minimum of five concentration values had to come from at least five different facilities to meet the minimum requirements to determine a TPC value. In comparing the two methods, some states had considerably lower nutrient loads using the new method because this approach decreases the positive or negative bias that a single facility can have on the TPC value (fig. 3).

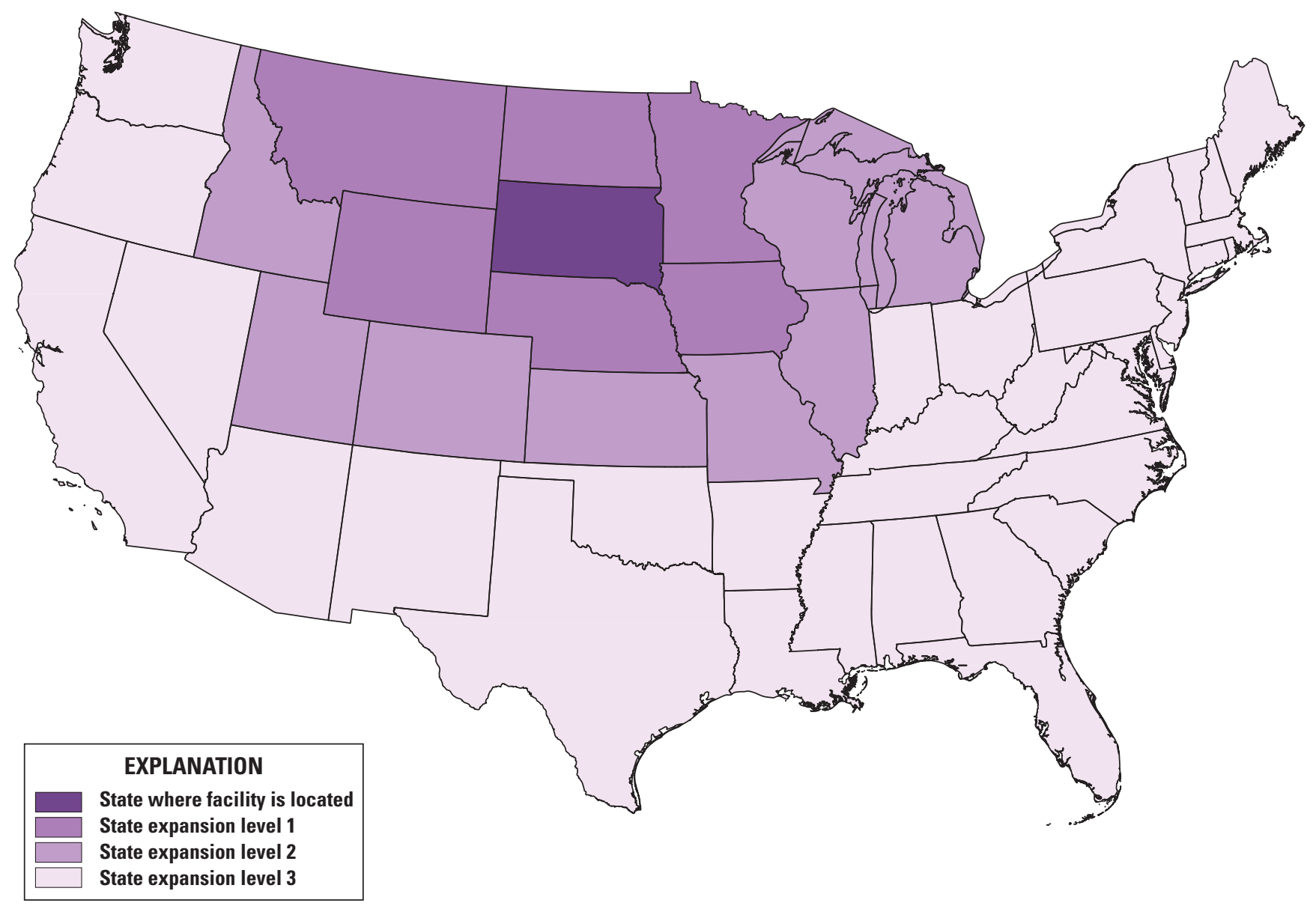

Figure 2. Example of state expansion levels for determining typical pollutant concentration values. 

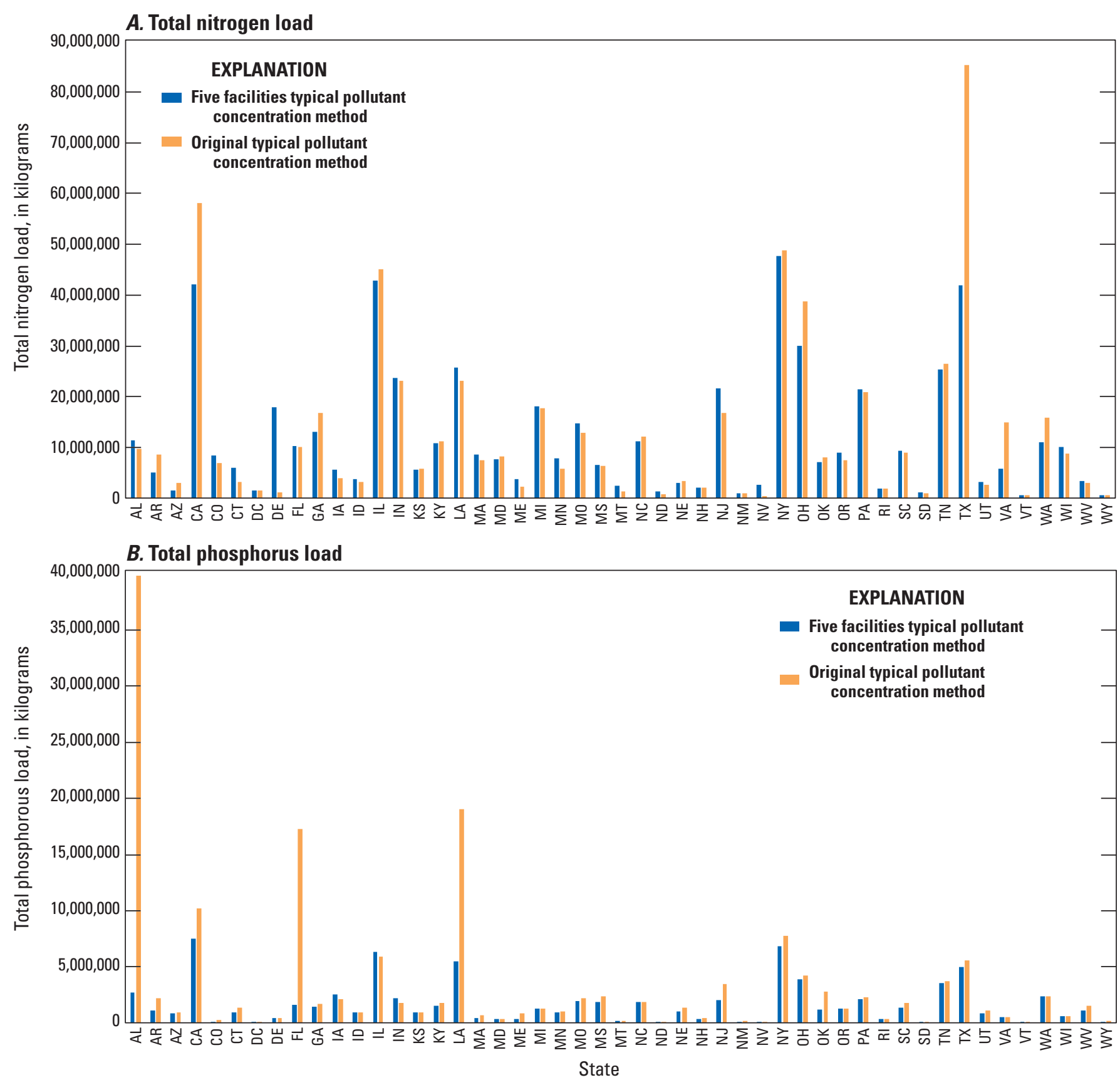

Figure 3. Comparison of nutrient loads from 2012 data derived from the Maupin and Ivahnenko (2011) method and the varying concentration and facility typical pollutant concentration method.

\section{Effluent Nutrient Load Calculation}

Annual point-source nutrient loads were calculated using the methods of McMahon and others (2007) and Maupin and Ivahnenko (2011) with the changes described in the previous section, "Updated Methods from Previous Studies." The loads were calculated as the effluent flow in million gallons per day (Mgal/d) multiplied by the number of days in the month and the nutrient effluent concentration (in milligrams per liter), converted to kilograms per month and summed for the year. If less than 12 months of flow data were available at a facility for the year but flow data for three or four seasons were available, then it was presumed that the facility discharged each month of the year and the flow data were missing and could not be recovered. In this case, seasonal median flow and nutrient concentrations were calculated from available data and seasonal loads were calculated by using the number of days in the season instead of monthly loads by using the number of days in the month. Annual loads were then calculated by summing the seasonal loads. If a facility had less than three seasons of effluent flow data, then monthly loads were calculated for the available months only and summed for an annual load. In this case, it was thought that the facility discharged only for part of the year. 
Like McMahon and others (2007) and Maupin and Ivahnenko (2011), a hierarchical approach to assign TPC values for facilities lacking effluent nutrient concentrations was used for this study. Assigned TPC values have a geographic priority over facility similarity. Effluent nutrient concentration assignments by decreasing priority were:

1. Use measured effluent nutrient concentrations for all 12 months in 2012.

2. If one or two months of a season were missing effluent nutrient concentrations, then a seasonal median value was calculated for effluent data.

3. If no effluent nutrient concentration data were available for a season, then monthly TPC values were used. A TPC value was derived from similar facilities in the state of interest based on decreasing facility similarities. This study used a minimum of five concentration values from at least five different facilities to calculate a TPC value.

a. The TPC was derived from facilities of the same size (flow class), type (SIC code plus treatment level if a WWTF), and season from within the state.

b. If not enough effluent nutrient concentration data were available to meet the requirement described in number 3.a., then a TPC was derived from facilities of the same size and type from within the state.

c. If not enough effluent nutrient concentration data were available to meet the requirement described in number 3.b., then a TPC was derived from facilities of the same type from within the state.

4. If not enough effluent nutrient concentration data were available to meet the conditions described in number 3, then the same evaluation process would continue within the state expansion level 1 (fig. 2). The evaluation steps $\mathrm{a}-\mathrm{c}$ in number 3 are repeated at state expansion level 1 .

5. If not enough effluent nutrient concentration data were available to meet the requirement described in number 4 , then the same evaluation process continues within the state expansion level 2 (fig. 2). The evaluation steps a-c in number 3 are repeated at state expansion level 2.

6. If not enough effluent nutrient concentration data were available to meet the requirement described in number 5 , then the same evaluation process continues (steps a-c) within the conterminous United States (fig. 2).

7. If none of these options provided a TPC nutrient concentration, a national SIC-specific TPC value was used. Maupin and Ivahnenko (2011) described this dataset as SIC-specific TPC values.
These methods were incorporated into the Point Source Load Estimation Tool (PSLoadEsT) (Gorman-Sanisaca and others, 2018). PSLoadEst was written using the open-source programming language $\mathrm{R}$ and has an easy-to-use interface written in Visual Basic for Applications ${ }^{\circledR}$ within a Microsoft Access ${ }^{\circledR}$ database file that guides the user through the options to estimate point source loads using the methods described in this report.

\section{Point-Source Nutrient Loads}

Point-source nutrient loads were estimated for all major point-source facilities and all minor WWTFs in the conterminous United States. Point-source facility, discharge, and nutrient concentration data and all load estimates are available from Skinner and Wise (2018). Nutrient loads were calculated for 5,430 major point-source facilities and 11,537 minor WWTFs for a total of 16,967 point-source facilities contributing nutrient loads to streams in the conterminous United States in 2012. Of the 16,967 facilities, 20 percent of the $\mathrm{TN}$ values are measured concentrations and the other 80 percent are TPC-derived concentrations. For TP, 37 percent were measured concentrations and 63 percent were TPC-derived concentrations. These ratios of measured concentrations and TPC values vary by state. For example, the facilities in the District of Columbia all have measured TN and TP concentrations (no TPC values), whereas Indiana and Wisconsin have the lowest percentage of measured TN concentrations (4 percent) and Iowa and Texas have the lowest percentage of measured TP concentrations ( 9 percent) (fig. 4).

The TN and TP loads also vary by state (fig. 5 ). The three states with the highest TN loads are the same as those for TP loads: California, Illinois, and New York. The largest contributor of nutrient loads to streams are WWTFs of various treatment levels, SIC code 4952 plus treatment level (fig. 6). Petroleum refining (SIC 2911) also is a large contributor of TN loads to streams; however, it does not contribute a significant amount of TP loads to streams. Several types of manufacturing facilities (for example, facility types SIC 2011, 2034, 2041, and so forth) contribute TP but not TN loads.

These facility types include: wet corn milling (SIC 2046), pulp mills (SIC 2611), paper mills (SIC 2621), industrial inorganic chemicals, not classified elsewhere (SIC 2819), and industrial organic chemicals, not classified elsewhere (SIC 2869).

WWTFs (SIC 4952) contribute most nutrient loads to streams (fig. 6). However, even though there are 11,396 minor WWTF dischargers (73 percent of the total WWTFs) and 4,218 major WWTF dischargers (27 percent of the total WWTFs), the major discharging WWTFs contribute 94 percent of the TN load and 93 percent of the TP load to streams (fig. 7). 


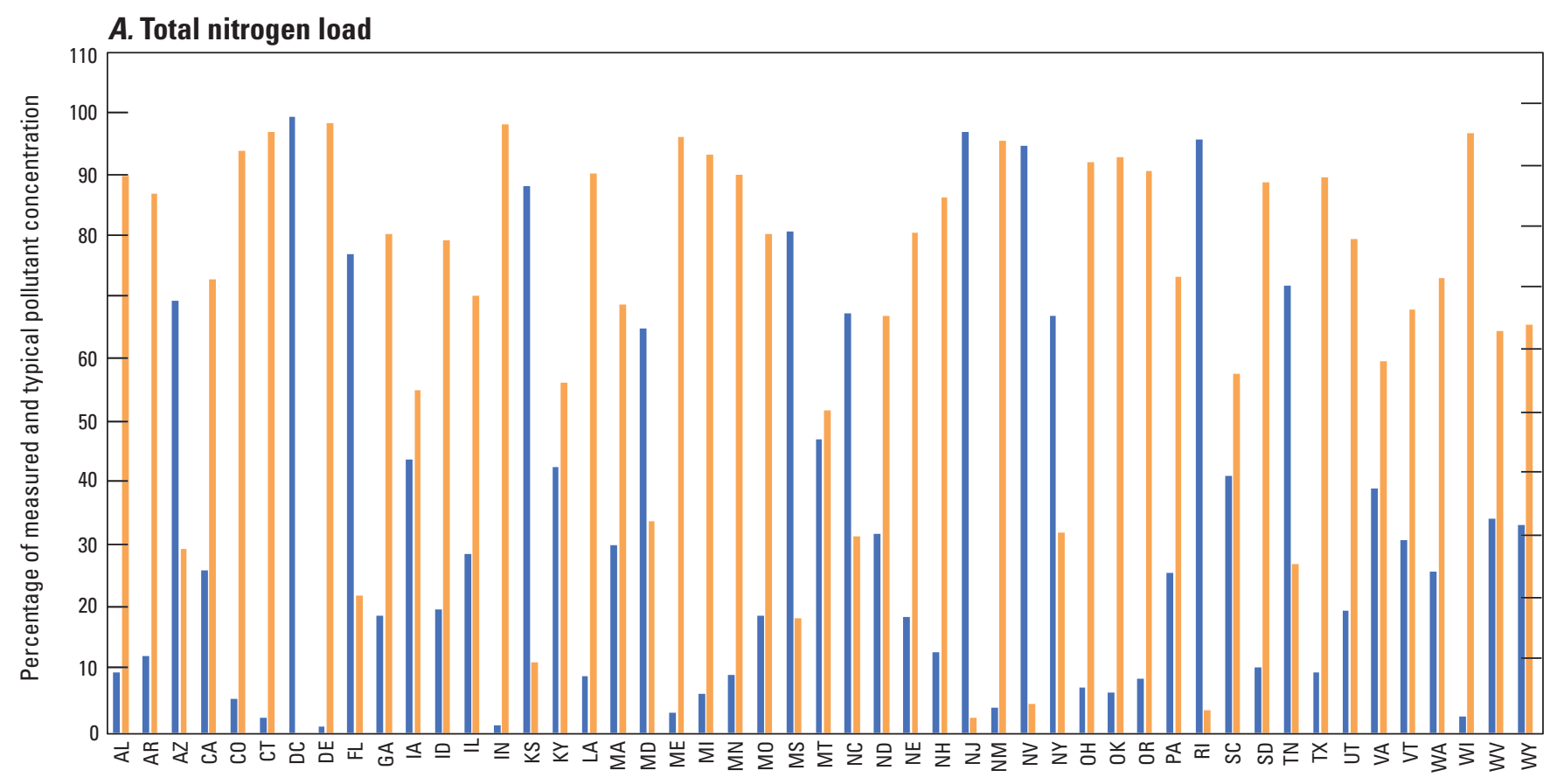

EXPLANATION

Load delivered from measured concentrations
Load delivered from typical pollutant concentrations

B. Total phosphorus load

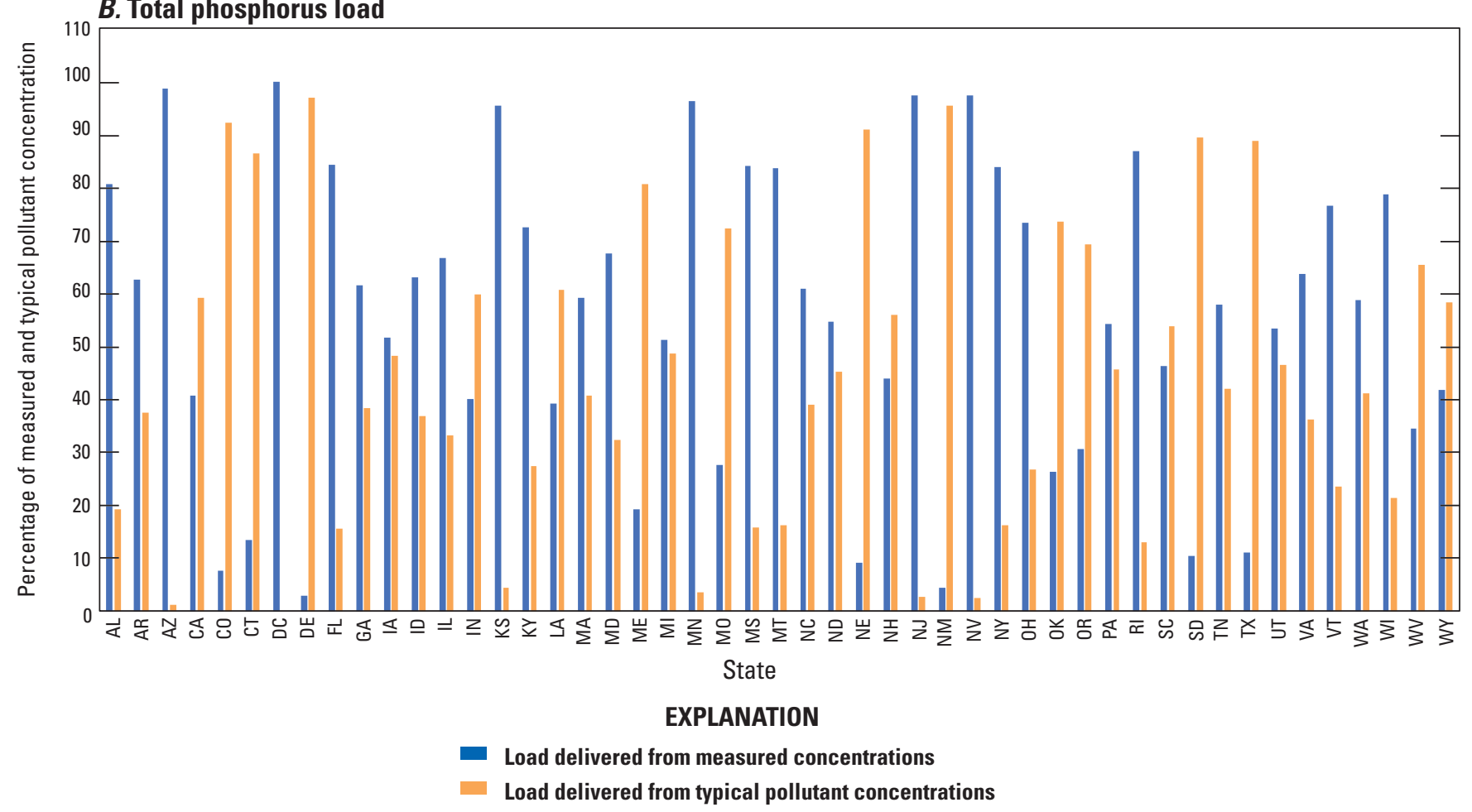

Figure 4. Percentage of measured and typical pollutant concentration values used to determine nutrient loads to streams by state, 2012. 

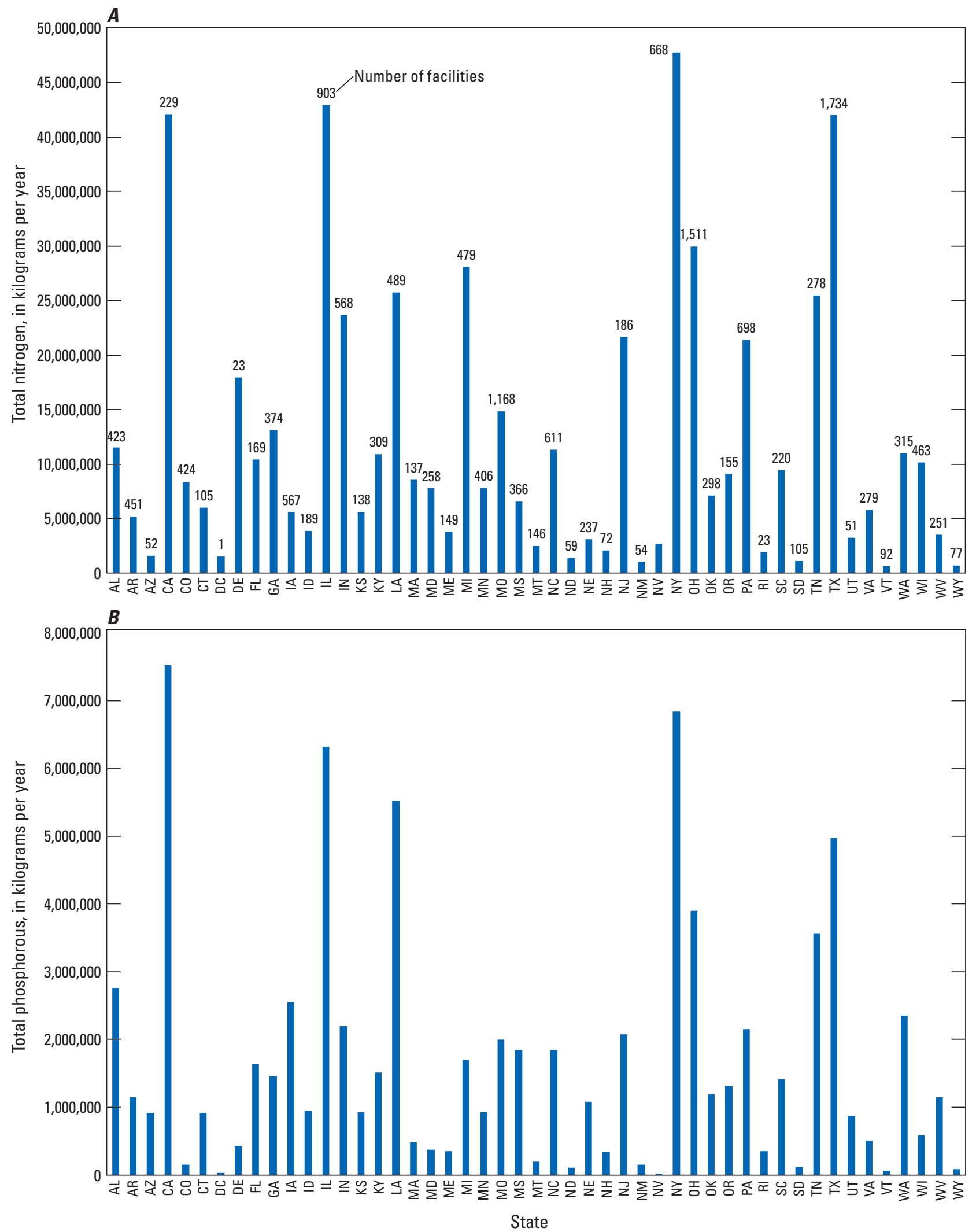

Figure 5. Total nitrogen $(A)$ and phosphorous $(B)$ loads in streams by state, 2012. 


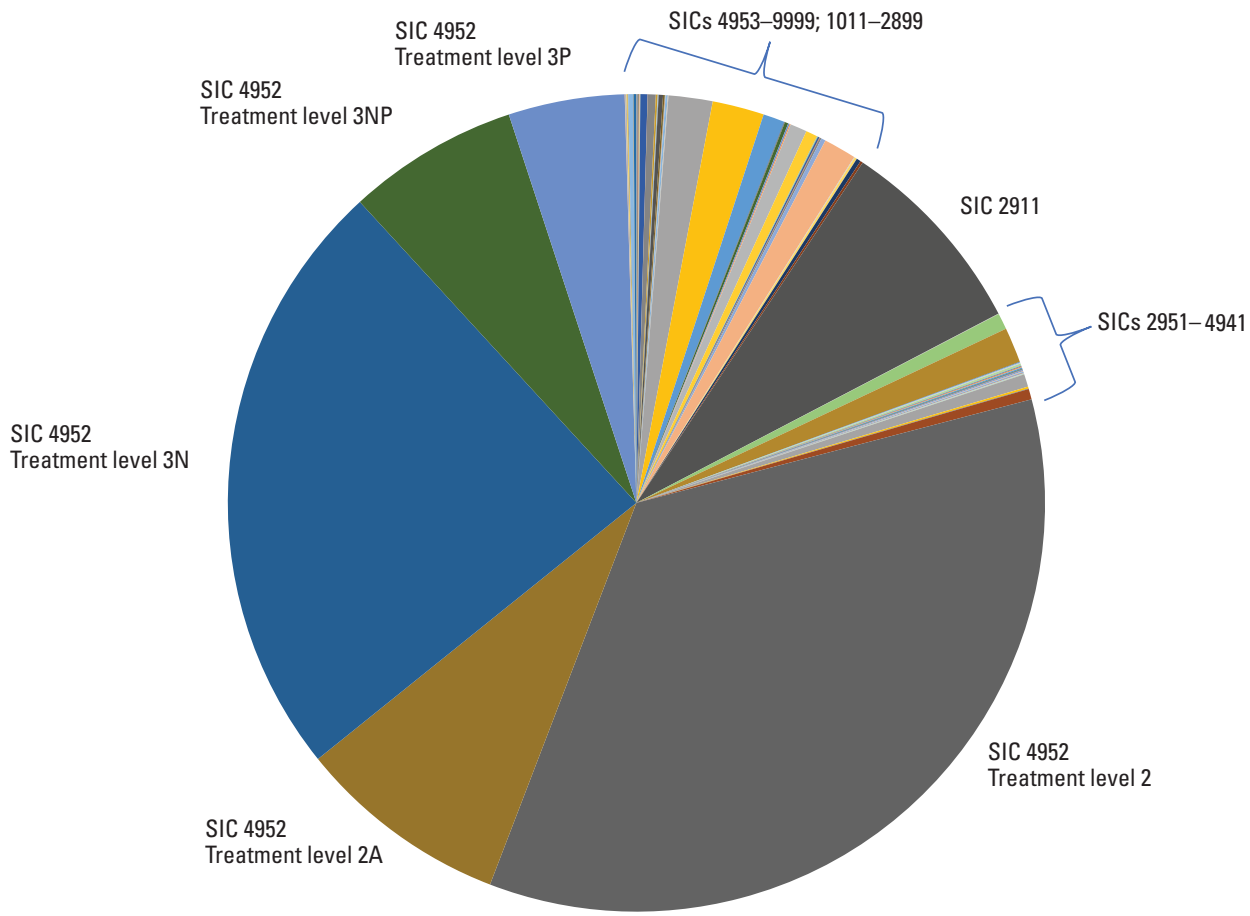

A. Total nitrogen load, in kilograms, by facility type (Standard Industry Classification) and treatment level if SIC $=4952$

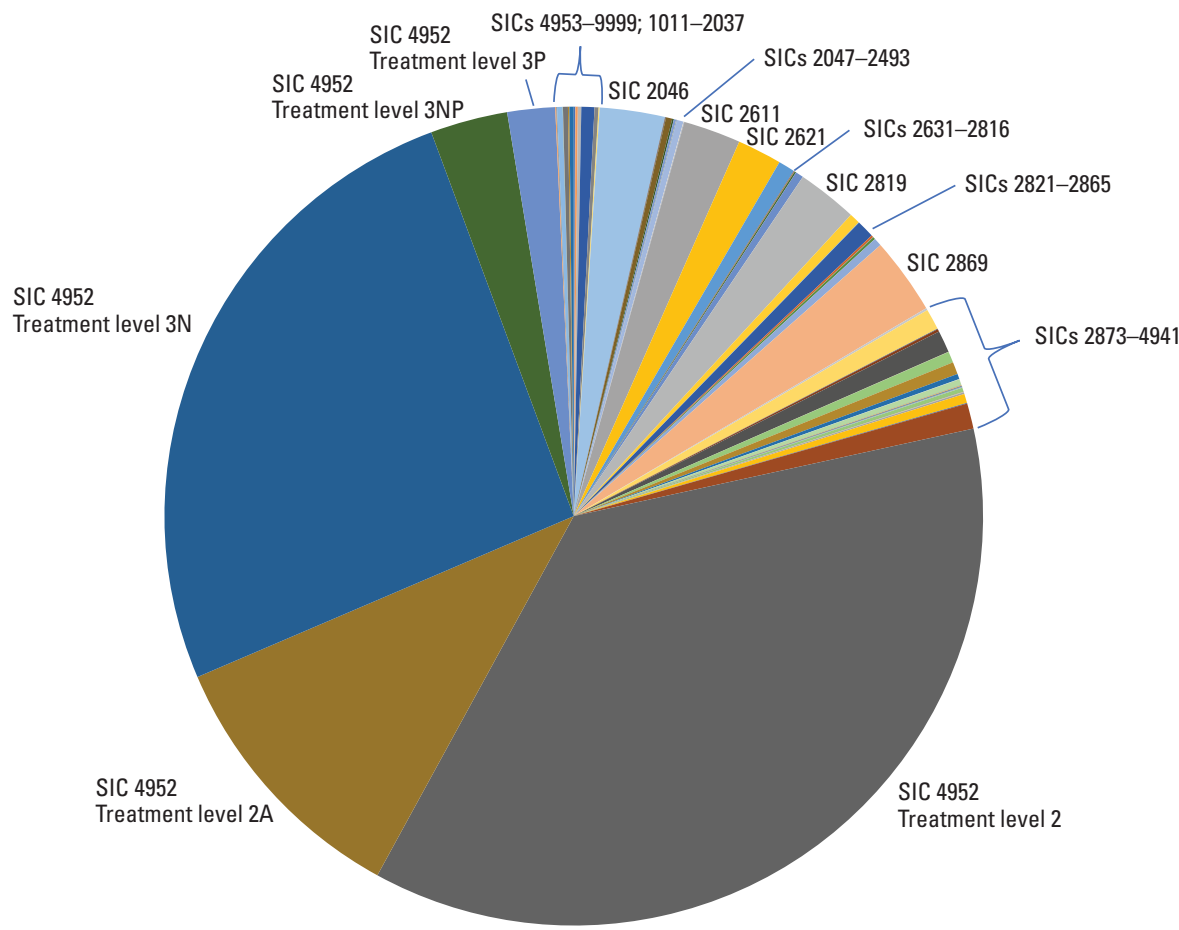

B. Total phosphorous load, in kilograms, by facility type (Standard Industry Classification) and treatment level if SIC $=4952$

Figure 6. Total nitrogen $(A)$ and total phosphorous $(B)$ loads by standard industry classification code (SIC) and treatment level for 2012. 

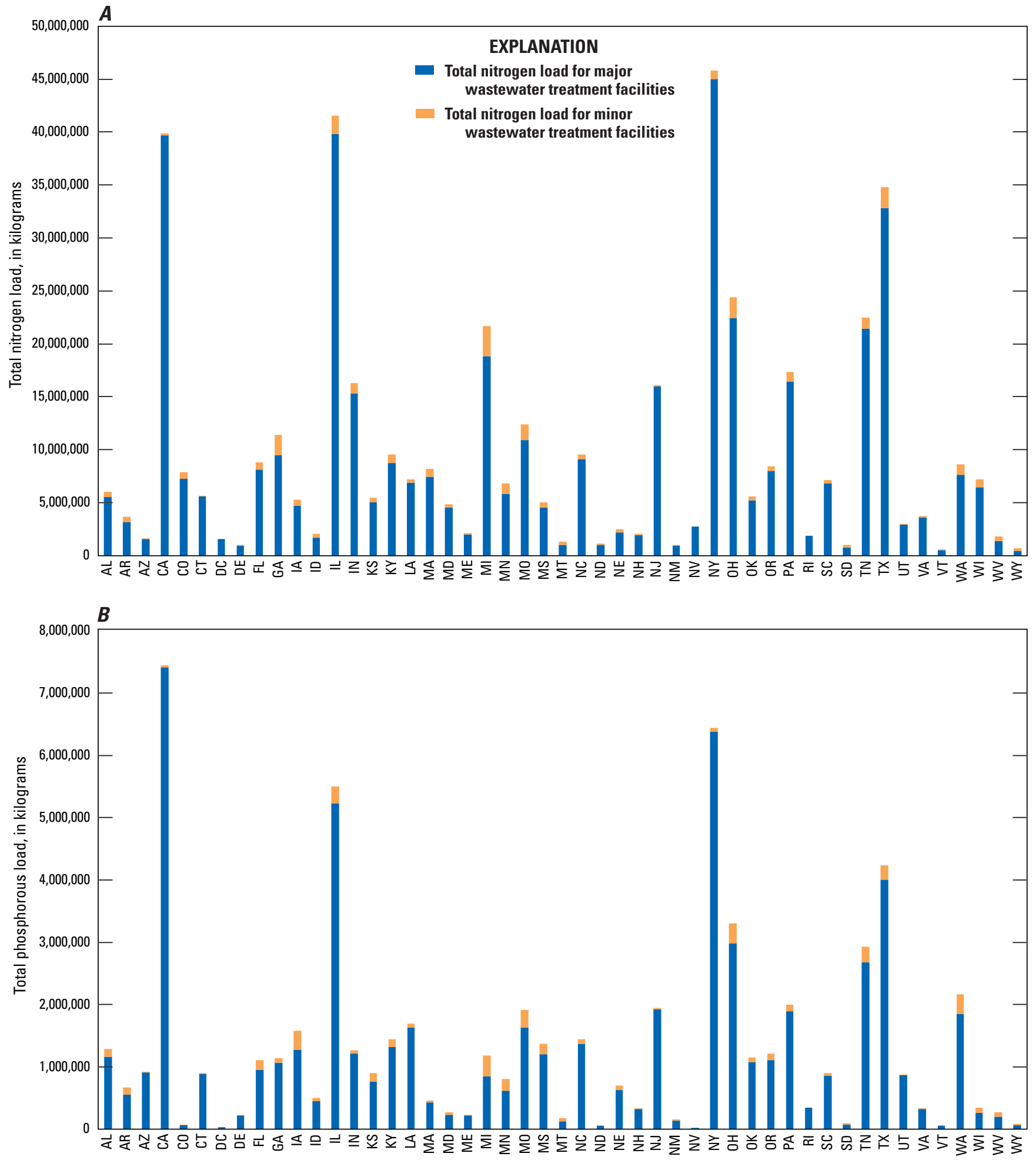

State

Figure 7. Total nitrogen $(A)$ and total phosphorous $(B)$ loads by major and minor wastewater treatment facilities in states for 2012. 


\section{Summary}

Total nitrogen (TN) and total phosphorous (TP) loads were estimated for 5,430 major point-source facilities and 11,537 minor wastewater treatment facilities (WWTFs) discharging to streams in the conterminous United States during 2012. Facilities classified as a major discharger are typically a facility that discharges greater than one million gallons of water per day however some industrial facilities are classified as a major based on specific criteria developed by the U.S. Environmental Protection Agency (EPA) and the National Pollutant Discharge Elimination System state program. This study used a new method for determining typical pollutant concentrations (TPC) in the absence of measured TN or TP concentration data. This new method allows for a varying amount of nutrient concentration data and, varying number of facilities from which the concentration data is derived, or both. For this study, concentration values were used from a minimum of five facilities to determine a TPC value for that type of facility. This is an important feature because it decreases the possibility of any single facility with large nutrient concentrations affecting the loads derived by TPC concentrations, especially because most of the nutrient loads are determined from TPC concentrations.

Major WWTFs with varying levels of treatment were the largest contributor of nutrient loads to streams even though there were almost three times as many minor WWTFs. TN loads primarily were from WWTFs and some petroleum refining facilities. TP loads also primarily were from WWTFs, but several manufacturing facilities such as corn milling, pulp and paper mills, and industrial chemical facilities also contributed TP loads.

\section{References Cited}

Alexander, R.B., Smith, R.A., Schwarz, G.E., Boyer, E.W., Nolan, J.V., and Brakebill, J.W., 2008, Differences in phosphorus and nitrogen delivery to the Gulf of Mexico from the Mississippi River Basin: Environmental Science and Technology, v. 42, no. 3, p. 822-830, accessed August 21, 2018, at https://doi.org/10.1021/es0716103.

Gorman-Sanisaca, L., Skinner, K.D., and Maupin, M., 2019, Annual wastewater nutrient data preparation and load estimation using the Point Source Load Estimation Tool (PSLoadEsT): U.S. Geological Survey Open-File Report 2019-1025, 48 p., https://doi.org/10.3133/ofr20191025.
Ivahnenko, T., 2017, Evaluation and use of U.S. Environmental Protection Agency Clean Watersheds Needs Survey data to quantify nutrient loads to surface water, 1978-2012: U.S. Geological Survey Scientific Investigations Report 2017-5115, 11 p., accessed August 21, 2018, at https://doi.org/10.3133/sir20175115.

Maupin, M.A., and Ivahnenko, T., 2011, Nutrient loadings to streams of the continental United States from municipal and industrial effluent: Journal of the American Water Resources Association, v. 47, no. 5, p. 950-964, accessed August 21, 2018, at https://doi.org/10.1111/j.1752-1688.2011.00576.x.

McKay, L., Bondelid, T., Dewald, C., Johnston, J., Moore, R., and Rea, A., 2012, NHDPlus Version 2: User Guide, accessed July 26, 2017, at ftp://ftp.horizon-systems.com/ NHDplus/NHDPlusV21/Documentation/NHDPlusV2_ User_Guide.pdf.

McMahon, G., Tervelt, L., and Donehoo, W., 2007, Methods for estimating annual wastewater nutrient loads in the southeastern United States: U.S. Geological Survey OpenFile Report 2007-1040, 81 p., accessed August 21, 2018, at https://pubs.er.usgs.gov/publication/ofr20071040.

Preston, S.D., Alexander, R.B., and Wolock, D.M., 2011, SPARROW modeling to understand water-quality conditions in major regions of the United States-A featured collection introduction: Journal of the American Water Resources Association, v. 47, no. 5, p. 887-890, accessed August 21, 2018, at https://doi.org/10.1111/j.17521688.2011.00585.x.

Robertson, D.M., and Saad, D.A., 2011, Nutrient inputs to the Laurentian Great Lakes by source and watershed estimated using SPARROW watershed models: Journal of the American Water Resources Association, v. 47, no. 5, p. 1011-1033, accessed August 21, 2018, at https://doi. org/10.1111/j.1752-1688.2011.00574.x.

Schwarz, G.E., Hoos, A.B., Alexander, R.B., and Smith, R.A., 2006, Section 3-The SPARROW surface water-quality model-Theory, applications and user documentation: U.S. Geological Survey, Techniques and Methods book 6 chap. B3, 248 p. and CD -ROM, accessed August 21, 2018, at https://pubs.er.usgs.gov/publication/tm6B3.

Skinner, K.D., and Wise, D.R., 2019, Point source nutrient loads to streams of the conterminous United States, 2012: U.S. Geological Survey data release, https://doi. org/10.5066/P9PYVPFT. 
Smith, R.A., Schwarz, G.E., and Alexander, R.B., 1997, Regional interpretation of water-quality monitoring data: Water Resources Research, v. 33, no. 12, p. 2781-2798, accessed August 21, 2018, at https://doi. org/10.1029/97WR02171.

U.S. Department of Labor, 2018, Occupational Safety and Health Administration SIC Manual, accessed August 21, 2018, at https://www.osha.gov/pls/imis/sic_manual.html.

U.S. Environmental Protection Agency, 1990, Permit Compliance System: U.S. Environmental Protection Agency, 20W-4001, $21 \mathrm{p}$.

U.S. Environmental Protection Agency, 2006a, Reassessment of point source nutrient mass loadings to the Mississippi River Basin, November, 2006: U.S. Environmental Protection Agency Mississippi River/Gulf of Mexico Watershed Nutrient Task Force, 31 p., accessed August 21, 2018, at https://www.epa.gov/ms-htf/report-point-sourceprogress-hypoxia-task-force-states.
U.S. Environmental Protection Agency, 2006b, Gulf hypoxia action plan 2008, accessed August 21, 2018, at https://www. epa.gov/ms-htf/gulf-hypoxia-action-plan-2008.

U.S. Environmental Protection Agency, 2018a, Clean Watersheds Needs Survey: U.S. Environmental Protection Agency, accessed February 27, 2018, at https://www.epa. gov/cwns.

U.S. Environmental Protection Agency, 2018b, PCS-ICIS Search: U.S. Environmental Protection Agency Web site, accessed February 22, 2018, at https://www.epa.gov/enviro/ pcs-icis-search.

U.S. Environmental Protection Agency, 2018c, Water Pollution Search: U.S. Environmental Protection Agency Web site, accessed February 22, 2018, at https://echo.epa. gov/trends/loading-tool/water-pollution-search. 

Publishing support provided by the U.S. Geological Survey Science Publishing Network, Tacoma Publishing Service Center

For more information concerning the research in this report, contact the Director, Idaho Water Science Center

U.S. Geological Survey

230 Collins Rd

Boise, Idaho 83702-4520

https://www.usgs.gov/centers/id-water 
